\title{
「地域リハビリテーションに関するリハビリテーション科医の意識調査」 に関するアンケート結果
}

日本リハビリテーション医学会 障害保健福祉委員会

$\begin{aligned} \text { 担当理事 } & \text { 蜂須賀研二 (前任) } \\ & \text { 朝貝 芳美 (平成 } 20 \text { 年 } 6 \text { 月から) } \\ \text { 委員長 } & \text { 小池 純子 (平成 } 20 \text { 年 } 9 \text { 月 } 30 \text { 日まで) } \\ & \text { 樫本 修 (平成 } 20 \text { 年 } 10 \text { 月 } 1 \text { 日から) } \\ \text { 担当委員 } & \text { 松坂 誠應, 武原 格 } \\ & \text { 鈴木 恒彦 (平成 } 20 \text { 年 } 9 \text { 月 } 30 \text { 日まで) } \\ \text { 委員 } & \text { 伊佐地 隆, 奥村 元昭, 篠原 裕治 } \\ & \text { 古澤 一成 }\end{aligned}$

\section{【はじめに】}

地域リハビリテーション（以下，地域リハ）は，開 発途上国における地域住民を活用した障害の予防とリ ハビリテーション（以下，リハ）や住みやすい地域づ くりの活動としてWHO（1981年）が提唱した ${ }^{1)}$. そ の後, 先進国の自立生活運動や障害者の消費者運動な どの影響を受け2， あらゆる地域や国でも通用する概 念に発展した ${ }^{3)}$.

その活動には, 保健医療だけでなく, 福祉や教育, 職業など幅広い分野が含まれている3 ${ }^{3)}$ そのため，包 括的な対応にはコーディネータの存在が必要であり, その役割としてリハ科医が期待されている. しかし，地 域リハの歴史が短いためか, 概念についても様々な理 解が報告されている ${ }^{4)}$. そのため, 地域リ八広域支援セ ンターなどを中心に地域リハの研修が行われている5 . 日本リハビリテーション医学会（以下，リハ医学会） 障害保健福祉委員会でも地域リハのあり方やこの領域 におけるリハ科医の役割を検討してきた。地域リハ支 援事業への医師の参加は低調で教育啓発が必要と報告 されているが5)，リ八科医についての調査はない。そ こで今回，地域リハに詨するリハ科医の関わりの現状 と今後の可能性などについてアンケート調査すること となった。

本調査の目的は，地域リハに対するリハ科医の関心 と参加の状況を明らかにし，リ八科医に対する教育研 修のあり方を検討することである。

\section{【方 法】}

リハ医学会会員（以下，会員）を対象に地域リハに 関するウェブ・アンケートを行った. 会員に対するア ンケートの周知はリハ医学会学術雑誌およびリハ ニュース, リハ医学会発行のメールマガジンで行った. 実施期間は 2009 年 1 月 5 日〜 3 月 31 日であった.

調査内容の概略を表 1 に示す.

会員の属性として年齢, 性別，勤務先を尋ねた。勤 務先の選択肢として「病院」「大学病院」「診療所」「介 護老人保健施設」「教育機関」「障害者支援施設」「更 生相談所」「その他」を挙げた。そのうち「病院」ある いは「大学病院」と回答した場合には「回復期リハ病 棟」の有無も尋ねた.

「地域リハへの関心」については「非常にある」「あ る程度ある」「あまりない」「全くない」の選択肢を挙げ た.さらに，「非常にある」あるいは「ある程度ある」 を選択した回答者には「地域リハ活動への参加」の有 無を尋ねた。

地域リハ活動に参加していた場合には，参加内容を 「直接的援助活動」「組織化活動」「従事者や住民への 教育啓発活動」に分けて尋ねた（表 1 ）。今回の調査 では「直接的援助活動」に「退院時や往診時の対応」も 含めた。また，各活動の参加頻度を「しばしば実施」 「時々実施」「まれに実施」「行っていない」から選んで もらった。

主な活動の場として, 非常勤での活動も含めて表 1 に示す選択肢から重複回答で選択してもらった。ま 


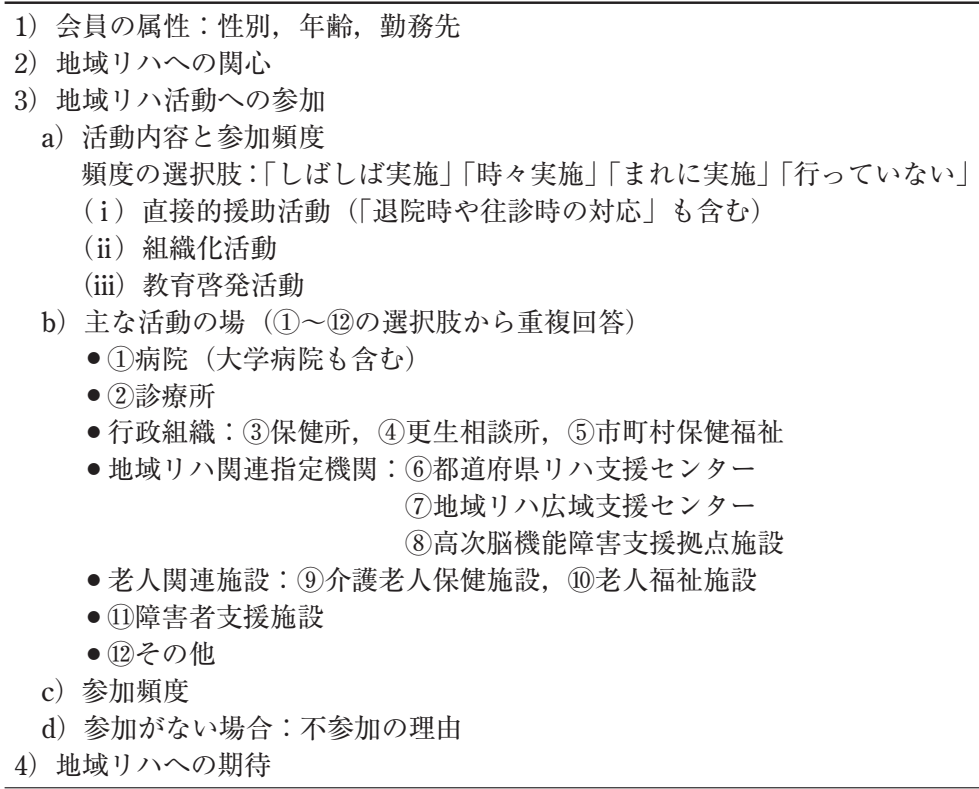

た，「病院」を選択した回答者には，活動の場が「回 復期リハ病棟」か否かも尋ねた。

地域リハ活動に参加していなかった場合には，その 理由について質問した。理由は「時間的余裕がない」 「参加する場が分からない」「活動のノウハウが分から ない」「職場の理解がない」「その他」の選択肢から重 複回答で選択してもらった。

「地域リハへの期待」について「非常にある」「ある程 度ある」「あまりない」「全くない」の選択肢を挙げ全 員に尋ねた。さらに，期待する分野についても尋ね た.

統計処理にはSPSS（11.5 日本語版）を用いた。調 査項目のクロス集計では $\chi^{2}$ 検定を行い，項目間の相 関関係の検定にはSpearmanの順位相関係数を用い た. 有意水準は $p<0.05$ とした.

\section{【結 果】}

\section{1. 単純集計の結果}

調査期間中のリハ医学会ホームページに登録してい た会員（以下，ログイン会員）は 1,996名であり，ア ンケートの回答者は 374 名〔男性 306 名 (82\%)，女 性 67 名 $(18 \%)$ ，不明 1 名】であり，すべて有効回答 であった。

回答者の平均年齢は $46 \pm 10$ 歳（27〜 80 歳）で，年 齢分布を図 1 に示す.

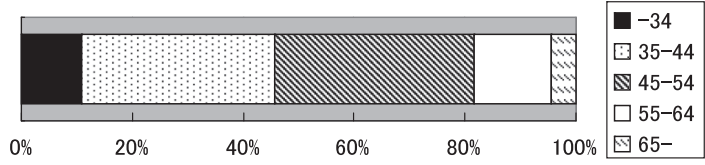

図 1 年齢分布

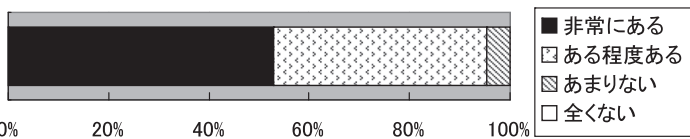

図 2 地域リハへの関心

勤務先では，「病院」〔230名 $(62 \%)]$ と「大学病院」 〔86 名 $(23 \%)] て ゙$ 全体の $85 \%$ を占めた。これらのう ち「回復期リ八病棟」の勤務医は 148 名で, 回復期リ 八病棟以外（以下，一般病棟）が 168 名であった。

「地域リハへの関心」について，「非常にある」197

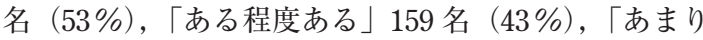
ない」 17 名 $(5 \%)$, 無回答 1 名であり，「全くない」 を選択したのものはいなかった（図 2)。「地域リハへ の関心」が「非常にある」あるいは「ある程度ある」も ののうち，地域リハ活動に参加した経験を持つものは 235 名（66\%，357 名中)，参加経験がないものは 122 名であった（34\%，357 名中）。

地域リハ活動に参加した経験のある 235 名の参加頻 度を図 3 に示すが，「直接的援助活動」への参加頻度 


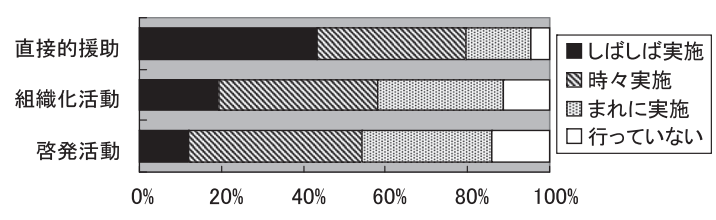

図 3 地域りハ活動への参加頻度

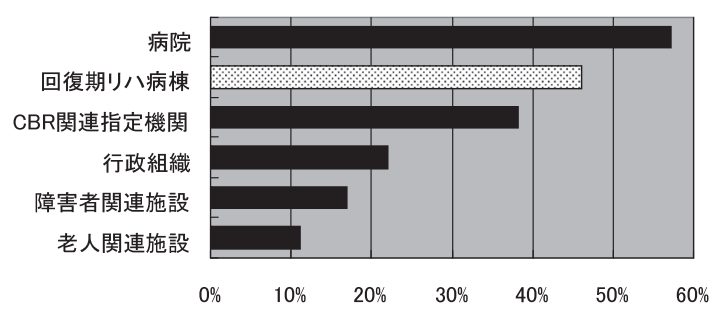

図 4 主な地域り八活動の場

「病院」 145 名は「回復期リ八病棟」 116 名を含む。

が他の「組織化活動」「従事者や住民への啓発活動」 に比べて多かった．また，主な活動の場は「病院」 $(57 \%)$ と「回復期リ八病棟」 $(46 \%)$ ，「地域リ八関 連指定機関」（38\%）が多かった（図 4).

地域リハ活動への参加経験がない 122 名に「参加し なかった理由」を尋ねたが，その結果，「参加する場が 分からない」 67 名 $(55 \%)$ ，「時間的余裕がない」 65 名 (54\%)「活動のノウハウが分からない」57名（47\%) であったささらに，条件が整えば参加するとしてもの は 106 名（87\%，122名中）であった。

「地域リハへの期待」を回答者全員に質問したが, 「非常にある」と「ある程度ある」で全体の $96 \%$ で，高 い期待が示された。そその期待する分野は「地域医療連 携」78\%，「介護予防」57\%などであった（図 5).

\section{2. クロス集計の結果}

「病院」を活動の場とするリハ科医は若い年齢層に 有意に多かった $(p=0.021)$. 特に「回復期リ八病棟」 では若い年齢層が有意に多く $(p=0.048)$ (図 6),「一 般病棟」では有意の差はないものの若い年齢層が多い 傾向だった $(p=0.065)$. それ以外の活動の場と年齢 層には有意の関係はなかった $(p>0.244)$.

地域リハへの関心と年齢層の関係には有意の相関関 係は認められなかったが $(p=0.073), 65$ 歳以上で関 心が高い傾向が認められた。また，活動の場が「回復 期リ八病棟」や「地域り八関連指定施設」の場合は, 地域リハへの関心が有意に高かった $(p=0.001, p=$ $0.021)$.

地域リハ活動への参加について, 年齢層との関係で

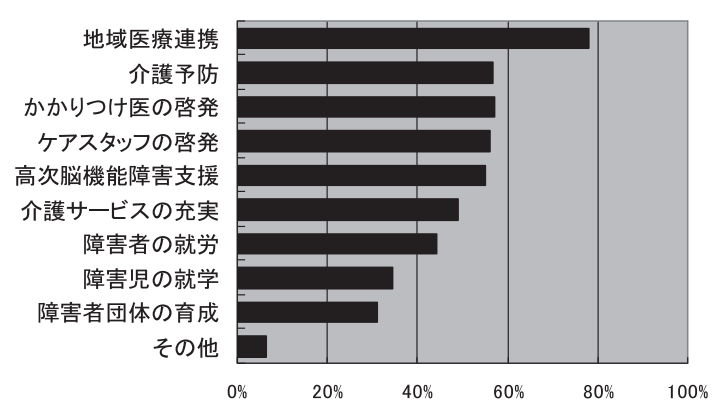

図 5 地域リハに期待する分野

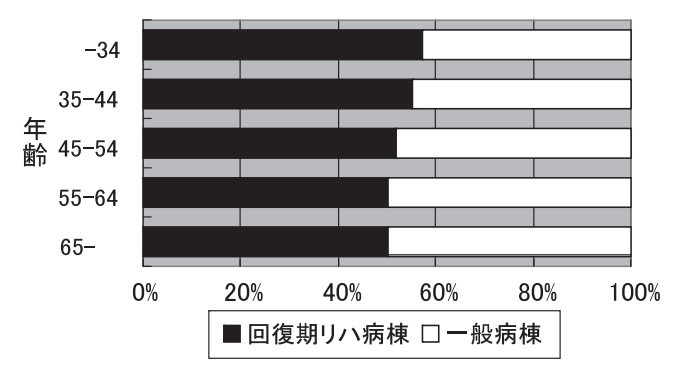

図 6 地域リハの活動の場（回復期リハ病棟） と年齢層の関係

$$
\text { Spearman 順位相関 } p=0.048
$$

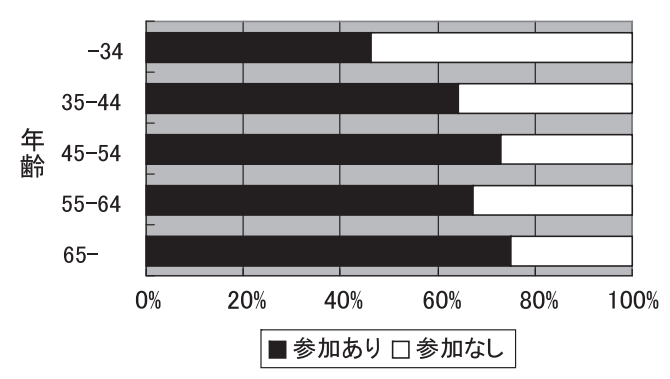

図 7 地域リハ活動への参加と年齢階層の関係 Spearman 順位相関 $p=0.016$

は，年齢層が高くなるにつれて活動への参加が有意に 多くなっていた $(p=0.016)$ (図 7).ささらに，活動の 場が「回復期リ八病棟」や「地域リ八関連指定施設」の 場合には，活動への参加が有意に多かった $(p=0.005$, $p=0.000)$.

地域リ八の活動内容において, 組織化活動と教育啓 発活動における参加頻度と年齢層の関係では, 年齢が 高くなるにつれて活動への参加頻度が有意に多くなっ ていた（いずれも $p=0.000 ）$. 直接的援助活動では有 意差は認められなかった $(p=0.846)$ (図 8).

地域リハ活動に関心はあるが参加経験がない 122 名 において, 不参加の理由と年齢階層の関係も検討し 


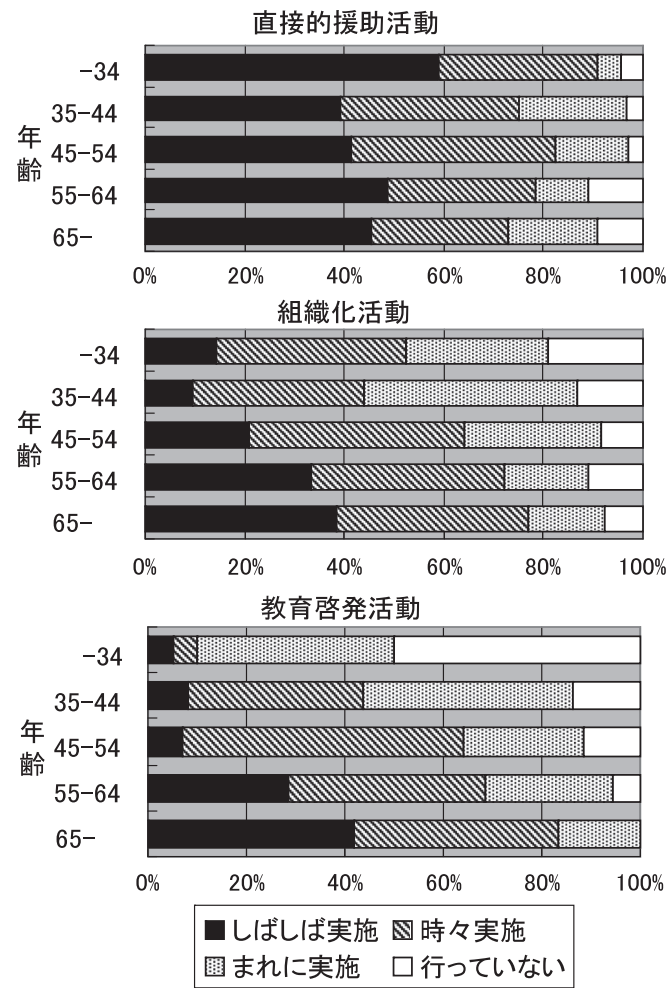

図 8 地域リハ活動への参加頻度と年齢階層の関係 直接的援助活動: Spearman 順位相関 $p=0.846$, 組織 化活動：Spearman 順位相関 $p=0.000$, 教育啓発活動： Spearman 順位相関 $p=0.000$

た。不参加の理由として「参加する場が分からない と回答したものは若い年齢層で有意に多く $(p=0.032)$ (図 9),「活動のノウハウが分からない」の場合でも 若い年齢層に多い傾向だった $(p=0.075)$.

また，「参加する場が分からない」と回答した者 （67名）を，年齢層と活動の場（「回復期リハ病棟」） のクロス集計を行った。その結果，「一般病棟」で活 動している若い年齢層が「参加する場が分からない」 と多く回答していた。さらに，「回復期リ八病棟」に 勤務している者のうち「参加する場が分からない」と 回答したリ八科医が 55 歳未満の各年齢層に $20 \%$ 前後 存在していた（図 10).

地域りハへの期待と年齢掞よび主な活動の場とのク ロス集計では有意差は認められなかった。

\section{【考 察】}

今回のアンケート調査はリハ医学会のホームページ を使った最初のウェブ・アンケートであり, 会員への

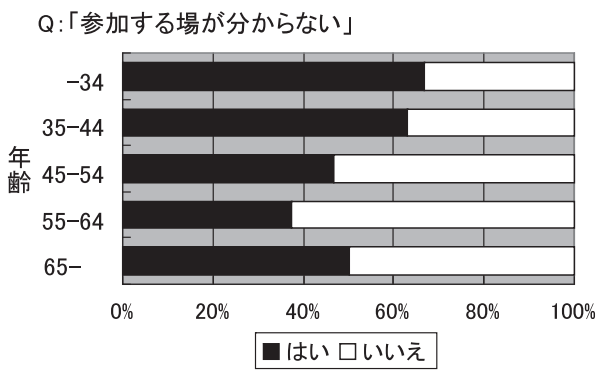

図 9 地域リハ活動への不参加の理由と年齢 階層の関係

Spearman 順位相関 $p=0.032$

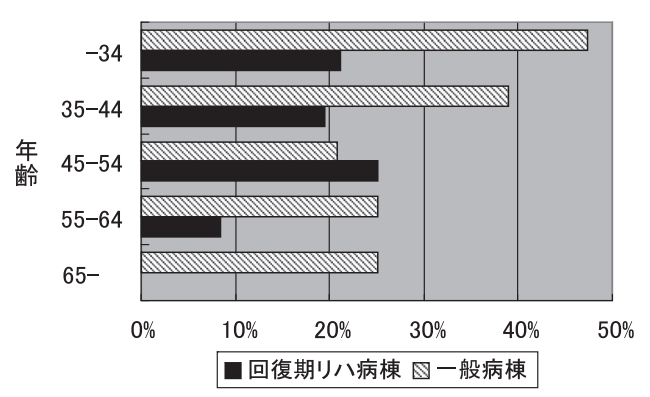

図 10 「参加する場が分からない」と回答した リハ科医の年齢層と活動の場（「回復期 リ八病棟」) の関係

アンケート周知はリハ医学会学術雑誌, リハニュース およびリハ医学会発行のメールマガジンであった。そ のため，アンケート調査表を直接会員に送付する従来 の方法と異なり，アンケート実施が全ての会員一人ひ とりに周知できたか疑問である。従って，アンケート 回収率はリ八医学会発行のメールマガジンを受信でき るログイン会員数 (1,996名) で，回答されたアンケー 卜数（374 件）を除したものと考えるが，18.7\%と極 めて低い数字となってしまう.

今回の回収率 $(18.7 \%)$ が低かった理由として，(1) 会員用ウェブシステムに対する関心が低い，(2)メー ルマガジンから会員用ホームページにアクセスできる URL が記載されていなかった，(3) アンケートに直接 アクセスできるシステムではなかったことも挙げられ る。しかし，回答者の $96 \%$ 「地域リハへの関心」 について「非常にある」あるいは「ある程度ある」と 答えていることを考慮すれば，今回の回答者は地域り 八に関心の高い集団であり，会員総体としての地域り ハへの関心は低い可能性が高い.

地域リハへの関心があるリハ科医（357名）のうち, 
地域リハ活動への参加経験があるものは $66 \%$ あ゙あ たが，若いリ八科医ほど地域リ八活動への参加が少な く, 活動頻度においても「組織化活動」と「教育啓発 活動」で若い年齢層では低調だった。

わが国における地域リハ活動は，老人保健法（1983 年）によって市町村に機能訓練事業が義務化されるこ とで全国的な展開となった ${ }^{6)}$. 各市町村では地域り八 に関するモデル事業が実施され，医師を含めた多くの 職種が参加する機会が与えられた。しかし，介護保険 制度開始後，市町村のモデル事業は減少するととも に, 医療制度の改訂に伴い医療機関から地域に出て行 う地域リハ活動が困難になってきた。その結果，若い 年齢層のリ八科医は地域リ八活動に参加する機会が減 少し，特に，地域リハのノウハウを必要とする「組織 化活動」や地域に出て行う場合が多い「教育啓発活 動」の頻度が少なくなったと考える.

リ八科医の地域リハ活動への参加が有意に多かった のは，活動の場が「地域リ八関連指定施設」だけでな く「回復期リ八病棟」の時でもあった。今回の調査で は, 地域りハ活動の「直接的援助活動」に在宅生活に 必要なサービスの調整, 福祉用具・住宅改修の処方な ど医療機関における「退院時の対応」も加えた。その ため, 活動の場が「回復期リ八病棟」の時にも地域リハ 活動への参加が多くなったと考える．地域リ八の概念は 病院など施設内リ八の見直しから発達してきたこと年 から考えると,「病院」内での活動を地域リ八活動に 加えるべきでないという考えもあるだろう。しかし， $2 つ の$ 活動はリハという戦略の中で連続した取り組み であり ${ }^{4)}$ ，医療機関から地域への「専門的サービス間

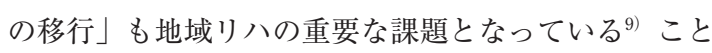
から，「回復期リ八病棟」で日常的に行われている「退 院時の対応」は地域リハの考え方に沿うものと考える べきであろう。

さらに, 活動の場を年齢層で検討すると,「地域り 八関連指定施設」では若い年齢層が少なく，逆に「回 復期リ八病棟」では若い年齢層が多かった. 先に, 若 い年齢層の地域リハ活動への参加が有意に少ないと述 べたが,「回復期リ八病棟」に若い年齢層が多いこと や「回復期リ八病棟」での活動が地域リハの考え方に 沿うということから，「回復期リ八病棟」は若い年齢 層に対する地域リハの啓発に貢献できる場の 1 つと考 える.

地域リハに関心がある者の約 $1 / 3$ は地域リハ活動に
参加していなかった．今回の調査の回答者は地域リハ に関心ある集団と前述したが，そのような集団でも参 加していないリ八科医が 3 割程度存在することにな る。しかも，「参加する場が分からない」，「時間的余 裕がない」,「活動のノウハウが分からない」という理 由で参加しておらず，その多くは条件が整えば参加す ると回答していた．特に，「一般病棟」に勤務してい る若い年齢層が「参加する場が分からない」と回答し ていた（図 10)。従って, 地域リ八の活動の場を明確 にするとともに実践的な教育啓発が重要な課題となっ てくる。これまで, 地域リ八広域支援センターなど 「地域リハ関連指定施設」は主にリ八専門職やケアス タッフに対する広報・研修活動を行ってきたが5), 若 い年齢層のリ八科医に対するプログラムも検討する必 要があるだろう.

「回復期リ八病棟」に勤務しているリ八科医でも, 若い年齢層において,「参加する場が分からない」と いう理由で地域リハ活動に参加していない者が若い年 齢層に約 20\%ずつ存在していた（図 10）。すなわち， 「回復期リハ病棟」で日常的に「退院時の対応」を 行っていても, それ自体が地域りハ活動と認識してい ない若いリ八科医がある程度存在していることにな る. 従って, このようなリ八科医には回復期りハと地 域リハの関連に関する啓発も必要になるだろう。

リ八科医の地域リハへの期待は高く, 期待する分野 として「地域医療連携」や「介護予防」が挙げられた。 これらは単に市町村の事業だけではなく, 日常のリハ 医療や対応にも深く関連することであり, 地域医療連 携や介護予防の意義についても研修を行う必要がある だろう.

\section{【まとめ】}

今回, リ八科医に対する地域リハの意識調査を行っ た. その結果, 若い年齢層において地域リ八活動への 参加が低調であり，参加していない理由は「参加する 場が分からない」「時間的余裕がない」「活動のノウハ ウが分からない」であった. しかし，その多くは条件 が整えば参加すると回答しており, 若い年齢層を対象 とした教育啓発が必要と考える.

また，地域り八活動は，地域で実施するものだけで なく,リ八医療機関に扔ける「退院時の対応」も在宅 生活へのソフトランディングに向けた対応であり, 地 域リハの考え方に沿うものである。しかし，今回の調 
査では，必ずしもこのような理解が得られている訳で はなかった。従って，リ八医療機関も地域リ八活動の 場であることを強調しておく必要があるだろう。

今回の回答率の低さを考慮すると，地域リハへのリ 八科医の理解は十分とはいえない．地域リハヘのリハ 科医の参画が強く求められている現在，「地域リ八関 連指定施設」の教育プログラムだけでなく，リ八科医 の系統的な教育プログラムに組み入れていくことが肝 要と思われる。

今回のアンケート調査にご協力いただきました会員の皆 様に深く感謝いたします，誌面の都合で，すべての項目， 特に自由記載分については揭載できませんでしたが，学会 のホームページなどを通して公表する予定です．皆様の貴 重なご意見は，今後の委員会の活動にも反映させていきた いと思います。

\section{文献}

1) WHO : Disability prevention and rehabilitation. WHO Technical Report No. 668, 1981

2) Lysack C, Kaufert J : Comparing the origins and ideolo- gies of the independent living movement and community based rehabilitation. Int J Rehabil Res 1994 ; 17 : 231-240

3) ILO, UNESCO, WHO : Community-based rehabilitation for and with the person with disabilities. Joint Position Paper (ILO, UNESCO, WHO), 1994

4) Peat M : Community based rehabilitation. in Community Based Rehabilitation. Queen's University, Ontario 2003 ; pp 27-47

5）浜村明徳, 松坂誠應, 他 : 地域におけるリハビリテーショ ンの実態とリハビリテーション手法・評価方法及び提 供体制に関する検討報告書（平成 16 年度厚生労働省 補助事業).日本公衆衛生協会, 2005

6) 大田仁史 : 地域リハ活動の歴史. 地域リハビリテーション 白書 2 (澤村誠志 監修). 三輪書店, 東京, 1998; pp 2-10

7) Helander E : Prejudice and Dignity : An Introduction to Community Based Rehabilitation. United Nations Development Program, New York, 1993

8) Helander E : CBR concept and principles - a historical perspective. NU News on Health Care in Developing Countries $1995 ; 9: 6-10$

9) WHO : 2nd meeting report on the development of guidelines for community-based rehabilitation (CBR). WHO http://www.who.int/disabilities/cbr/031105_CBR_ Guidelines_2nd_meeting_report.pdf (2009.11.7) 


\title{
急性期病院における回復期リハビリテーション病院への患者転院および 回復期リハビリテーション病院における患者受け入れについての アンケート調査の結果報告
}

\author{
日本リハビリテーション医学会 社会保険等委員会 \\ 担当理事 水間 正澄, 吉永 勝訓 \\ 委員長 川手 信行（報告担当） \\ 委員 古䦥 博明，近藤 克則，近藤 国嗣，菅原 英和 \\ 染屋 政幸, 高橋 博達, 長谷 公隆 \\ 原寛美, 藤谷 順子, 森 英二 \\ 尾花 正義, 古市 照人 (平成 21 年 9 月 30 日まで) \\ 稲川 利光，大串幹 (平成 21 年 10 月 1 日から)
}

\section{【はじめに】}

2008 年 4 月の診療報酬の改定において，回復期リ ハビリテーション（以下，リハ）病棟入院料の見直し が行われ，回復期リ八病棟入院料 1 が設定され，その 算定要件に重症例 $15 \%$, 自宅等退院が $60 \%$ 以上など の条件が加わったこと，そして重症患者 $30 \%$ 以上が 生活機能の改善した場合に重症患者回復病棟加算 50 点（1日につき）が算定できるなどの条件が新たに設 定された。

今回，私たちは，診療報酬改定後に回復期リハ病棟 への患者の受け入れ状況を調べるために，患者をゆだ ねる側の急性期病院と患者を受け入れる側の回復期り 八病院とにアンケート調査を行ったので報告する。

\section{【調查方法】}

1. 対 象：日本リ八医学会認定研修病院の指導担 当のリハ科専門医 467 名とした。

2. 方 法：急性期病院用抢よび回復期リ八病棟用 アンケート調查用紙を送り，2009 年 6 月 19 日までに, 272 病院・施設（回収率 $58.2 \%$ ) から Fax で回答送信 していただいた。このうち急性期病院用アンケート調 査に回答をいただいた 116 病院・施設，また，回復期 リハ病棟用アンケート調查に回答をいただいた 156 病 院・施設のうち亜急性期病棟や分析不可能な 4 病院・ 施設を除いた 152 病院・施設について解析した.

\section{【結 果】}

1. 急性期病院用アンケート調査の結果

回復期リ八病棟を有する病院へ，入院依頼をしたこ とのある病院は $77 \%$ (89病院)，したことのない病 院は $23 \%$ (27 病院) であり, 後者のほとんどが療育 センターなどの小児専用の病院であった（図 1).

回復期リハ病棟を有する病院へ入院依頼をしたこと のある 89 病院において, 2009 年 $1 \sim 3$ 月の 3 力月間 に急性期リハをリ八科専門医が担当し，回復期リ八病 棟を有する病院に転院した症例は約 2,900 人であった。 その内訳 (図 2) は， 1 人以上 20 人未満の患者を転院 させたとする病院が 35 病院と最も多く, 21 人以上 40 人未满が 21 病院, 60 人以上の病院が 12 病院, 41 人 以上 60 人未満が 12 病院の順であった。同時期にリハ 科専門医が『専門的リ八施設の転院と集中的な専門リ 八が医学的に適応』と判断したが，回復期リ八病棟を 有する病院へ転院できなかった症例（転院不可能症 例）は 835 人であり, 約 $22 \%$ 症例が転院できなかっ た（図 3)，その理由（表 1）について最も多かったの が酸素投与, 内科疾患，リスクなどの医学的管理の問 題があった例が $35 \%$, 発症から 2 力月超えになって しまった症例が $29 \%$ ，自宅退院のめどが立たないな ど社会的理由が $14 \%$ であた。

\section{2. 回復期リハ病棟用アンケート調查の結果}

回復期リ八病棟に他院からの患者を受け入れたこと がある病院は，回答のあった 152 病院中 147 病院であ り, 残り 5 病院は小児専門病院や, 病院内での患者の 


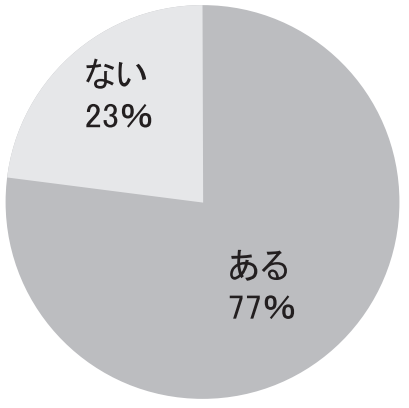

図 1 回復期リハ病棟を有する病院への患者依頼の有 無について $(n=116$ 病院・施設 $)$

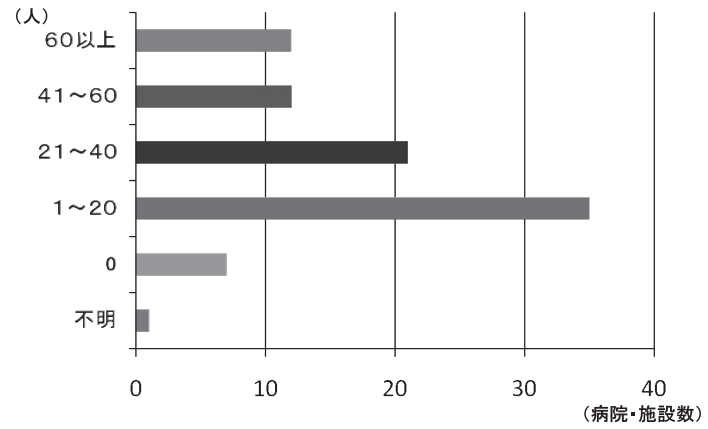

図 22009 年 $1 \sim 3$ 月の 3 カ月間に回復期リハに転院 した患者数（急性期病院） $(n=89$ 病院・施設

表 1 回復期リハ病院に転院できなかった理由（急性期病院） $(n=835$ 人）

(1) 疾患の治療または併存疾患・合併症の治療のために 2 カ月以内に転院できないため $(29 \%)$

(2) 医学的管理（酸素投与，高価な内服薬，内科疾患，リスク等）が困難であるため $(35 \%)$

(3) 自宅退院の目途が立っていないなど社会的理由があるため $(14 \%)$

(4) 頸䯣損傷・類似状態を受入れ可能な回復期リハ病棟のベッド数が極めて少ないため $(4 \%)$

(5) その他の理由による $(18 \%)$

【その他の理由：自由記載】（ ）内の数字は記載のあった病院・施設数

・家族の希望（他病院でもリハが受けられるので） (4)

・認知症のため (4)

・回復病棟へのベッド待ちが長く，その間に自宅退院や他院へ入院となった (4)

・人工透析患者が回復期病棟では診療報酬上受け入れてもらえない $(3)$

・身寄りの方がいない，保証人が不在のため $(2)$

・上腕骨折など疾患名の不適合や回復期リハ対象疾患に該当しなかった (2)

・ 入院時より介護保険で要介護 5 , 交通外傷重度障害であり ADL の回復が見込めない (2)

・居住地域に回復期病院がなく，紹介先の病院が遠方 $(2)$

・空床なし (2)

- 入院診療科（主治医）の意向（2）

・ワーファリンのような採血が必要な場合，包括でできない（1)

·TKA 術後の集中的な専門リハが整形外科病院でできるので, 回復期リ八に転院する必要がなかった (1)

・ 小児の脳外傷, 重度四肢麻瘦一障害児リ八施設に転院（1）

・高次脳機能障害のみ (ADL 自立) の患者のため (1)

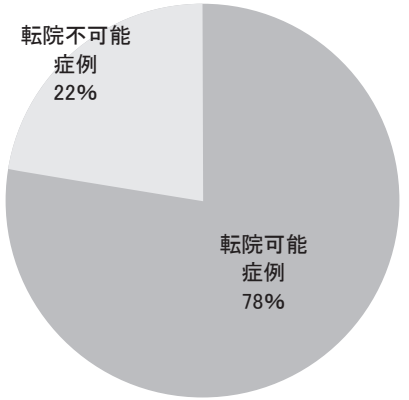

図 3 回復期リハへ転院可能症例と転院不可能症例の 割合（急性期病院） $(n=3,736$ 人）

みを受け入れている病院で一般病院や他院からの患者 の受け入れはしていなかった。
回復期リハ病棟に他院からの患者を受け入れたこと がある 147 病院において, 2009 年 $1 \sim 3$ 月の 3 力月 間に回復期リハ病棟に入院の依頼があった症例は, 12,368 人であり，そのうち脳血管障害症例の依頼が $59 \%$ ，骨関節疾患症例の依頼が $26 \%$ ，脊䯣損傷 $3 \%$ ， 神経筋疾患 $2 \%$ ，切断 $1 \%$ であった（図 4)。入院依頼 のあった症例のうち，実際に入院できた症例（入院可 能症例）は，9,396 人 $(76 \%)$ ，入院できなかった症例 （入院不可能症例）は 2,972（24\%）であった（図 5). そのうち，脳血管障害症例では $23 \%$ ，脊髄損傷症例 では $36 \%$ ，神経筋疾患症例では $26 \% ，$ 骨関節疾患症 例では $22 \%$, 切断症例では $31 \%$ 症例が入院できな かった（表 2).入院できなかった理由（入院不可能 


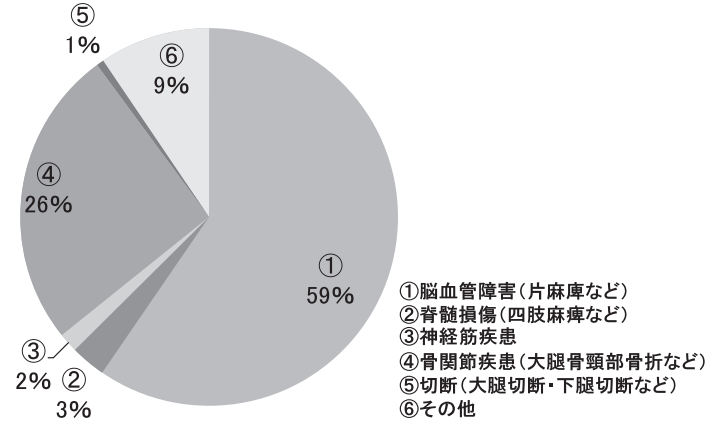

図 4 回復期リハ病棟へ入院依頼の疾患別内訳 $(n=12,368$ 人 $)$

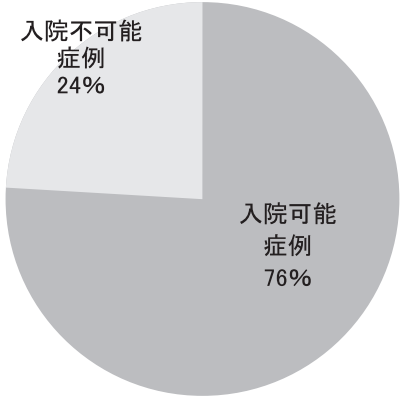

図 5 回復期病棟に入院可能症例と入院不可能症例の 割合（回復期リハ病棟） $(n=12,368$ 人）

表 2 疾患別に見た回復期リハ病棟に入院できた患者とできなかった患者の 割合（回復期リハ病棟）

\begin{tabular}{|c|c|c|c|c|c|c|}
\hline & (1) & (2) & (3) & (4) & (5) & (6) \\
\hline 入院可能症例（人） & 5,664 & 242 & 143 & 2,486 & 42 & 819 \\
\hline 入院不可能症例（人） & 1,697 & 139 & 49 & 687 & 38 & 362 \\
\hline 入院可能症例の割合（\%） & 77 & 64 & 74 & 78 & 53 & 69 \\
\hline
\end{tabular}

表 3 回復期リハ病院に入院不可能だった理由（回 復期病院 $)(147$ 病院の複数回答)

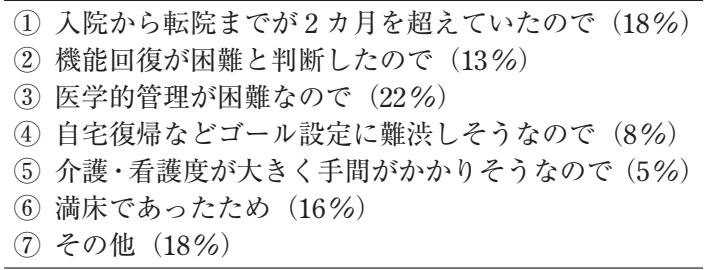

だった理由）は，総合的にみた場合（表 3)，医学的 管理が困難であるため $22 \% ，$ 発症から 2 カ月を超え ていたため $18 \%$ ，満床であったため $16 \% ，$ 機能回復 が困難と判断したため $13 \%$ の他，自宅退院などゴー ル設定が困難であったため $8 \%$ や看護度が大きく世話 の手間がかかる $5 \%$ どのような社会的問題もみられ た．疾患別でみた場合の入院ができなかった理由（入 院不可能だった理由）は表 4-1〜3にそれぞれ示した。

回復病棟を有する病院において, 入院依頼患者の入 院決定に至る手続きについては，回答のあった 134 病 院のうち,リハ科専門医などの医師が入院を判断する と答えた病院が $55 \%$ ，入院判定会議など各スタッフ 間の協議で入院を決定すると答えた病院が $40 \%$ で あった。 また，入院決定の前に家族や患者との面談が 必要な病院は, 29 病院 $(21.6 \%)$ であった（図 6).

\section{【まとめ】}

急性期病院で 2009 年 $1 \sim 3$ 月の 3 力月間に急性期 リハをリ八科専門医が担当し『専門的リ八施設の転院 と集中的な専門リハが医学的に適応』と判断したが, 回復期リ八病棟を有する病院へ転院できなかった症例 は全体の $22 \%$ あった。転院できなかった理由は, 酸素投与, 内科疾患, リスクなどの医学的管理上の問 題，および発症から 2 カ月を超えたためなどの制度上 の理由, 自宅退院のめどが立たないなどの社会的理由 が主であった。

逆に回復期リハ病棟を有する病院で入院依頼のあっ た症例のうち，実際に入院ができた症例は，9,396 例 (76\%)，入院ができなかった症例は $2,972(24 \%)$ で, 約 4 分の 1 の症例が入院できなかった。入院できな かった理由は，医学的管理が困難，発症から 2 力月超 えのため, 満床, 機能回復が困難と判断したためなど であった。

急性期病院側で回復期リハ病棟への転院の必要性を 認めたが，回復期リハ病棟を有する病院に入院できな かった症例の割合と回復期リ八病院に入院依頼をされ ながら入院できなかった症例の割合は約 20 数\%であ り，ほぼ同じ割合であった。このことから，急性期病 院から回復期リ八病棟を有する病院への転院困難例が 
表 4-1 回復期リハ病院に入院不可能だった理由 (回復期病院 $)$ (147 病院の複数回答)

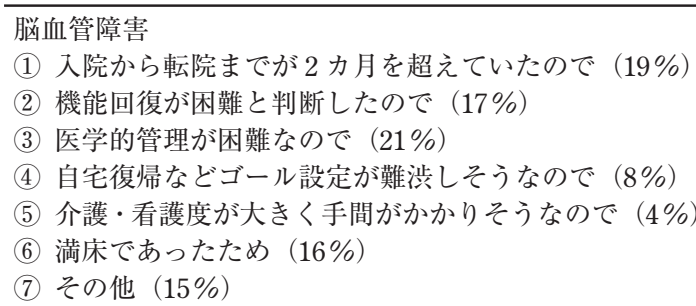

\section{春髄損傷}

(1) 入院から転院までが 2 力月を超えていたので（18\%）

(2) 機能回復が困難と判断したので $(11 \%)$

(3) 医学的管理が困難なので $(22 \%)$

(4) 自宅復帰などゴール設定に難渋しそうなので $(6 \%)$

(5) 介護・看護度が大きく手間がかかりそうなので (8\%)

(6) 満床であったため $(16 \%)$

(7) その他 $(19 \%)$

\section{神経筋疾患}

(1) 入院から転院までが 2 カ月を超えていたので (21\%)

(2) 機能回復が困難と判断したので (14\%)

(3) 医学的管理が困難なので $(21 \%)$

(4) 自宅復帰などゴール設定に難渋しそうなので $(9 \%)$

(5) 介護・看護度が大きく手間がかかりそうなので $(5 \%)$

(6) 満床であったため $(18 \%)$

(7) その他 $(12 \%)$
表 4-2 回復期リハ病院に入院不可能だった理由 (回復期病院)（147 病院の複数回答）

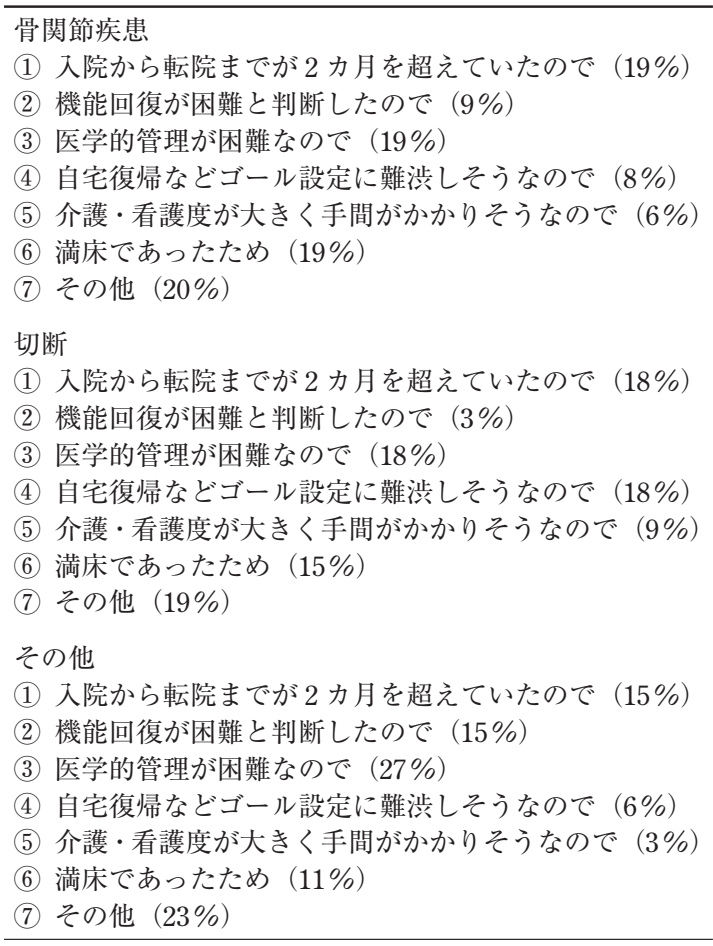

表 4-3 回復期リハ病院に入院できなかった理由（回復期病院）（147 病院の 複数回答：数字は自由記載のあった病院・施設数を示す)

\begin{tabular}{|c|c|c|c|c|c|c|}
\hline (7) その他の理由の自由記載例 & (1) & (2) & (3) & (4) & (5) & (6) \\
\hline 回復期リハ対象外疾患のため & 1 & 2 & 1 & 3 & 1 & 4 \\
\hline 回復期リハ適応なし & 3 & & & 1 & 1 & 2 \\
\hline 障害が軽度なので在宅復帰・外来へ & 10 & 2 & 2 & 4 & 2 & 6 \\
\hline 入院前にキャンセル & 3 & 1 & 1 & 3 & 1 & 3 \\
\hline 入院前に他院へ入院 & 12 & 7 & & 7 & 2 & 7 \\
\hline 認知症・精神症状のため & 4 & 3 & & 8 & 0 & 3 \\
\hline 状態悪化・不安定のため & 8 & 1 & & & & 1 \\
\hline 対応困難・人材不足のため & & 1 & & 2 & 1 & 1 \\
\hline 他県在住のため & & 1 & & & & 1 \\
\hline 入院中に期限越えの可能性があるため & & 2 & & & & \\
\hline 小児 GBS & & & 1 & & & \\
\hline 脳血管障害のみ入院適応 & & 1 & & & & \\
\hline ターミナルだったので & & & & & & 1 \\
\hline 長期入院希望 & 1 & & & & & \\
\hline
\end{tabular}

(1)脳血管障害, (2)脊髄損傷, (3)神経筋疾患, (4)骨関節疾患, (5)切断, (6)その他

$20 \%$ 以上存在することが推測された。そして，急性 期病院から転院できなかった理由と回復期リハ病棟を 有する病院へ転院できなかった理由の上位の 2 つは共
通した事項であり，リスク管理などの医学的管理の問 題と発症から 2 カ月超えの制度上の問題であった。

したがって，回復期リハ病棟では医学的管理が困難 


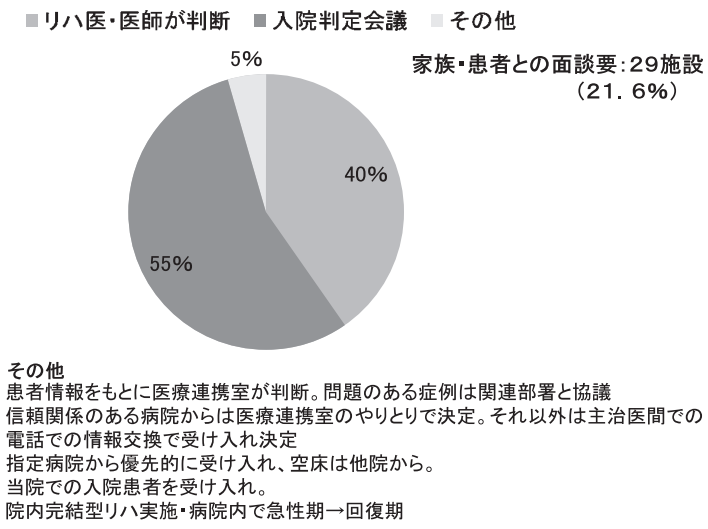

図 6 患者の入院決定方法（回答のあった回復期リハ 病院 $: n=134$ 病院)
である患者のリハの場をいかに確保するかが今後の課 題であり，また重度機能障害をもつ患者などでは回復 期リ八病棟へ入院できるまでの期間を延長するなどの ルール変更も必要であると考えられた。

アンケートにご協力をいただいた，日本リ八医学会認定 研修病院の指導担当のリ八科専門医の諸先生方に感謝いた します. 


\section{海外の専門医制度についてのセミナー}

横浜市立大学附属病院リハビリテーション科 菊地 尚久

2009 年 10 月 20 日に東京ステーションコンファレ ンスに扔いて日本専門医制評価・認定機構の主催で 「海外の専門医制度についてのセミナー」が開催され， 米国専門医制機構の理事長である Kevin B Weiss 先生 とドイッで専門医制度に長年関わってこられた福祉村 病院長寿医学研究所所長の堀映先生がご講演されまし た．本セミナーは日本リハビリテーション医学会の先 生方にも参考になる内容と思われましたのでこの概要 についてここに報告いたします。

\section{講演 I}

\section{Physician Specialty Board Certification in the United States}

\section{Kevin B WeISS}

President and CEO, American Board of Medical Specialties (ABMS)

米国シカゴのノースウェスタン大学内科教授の Weiss 先生から米国専門医制度に関する講演がありました。 米国の専門医制度は現在 75 年以上の歴史があり，一 般市民の専門医に対する要望に応えるために独立した 組織として設立されました。

米国の医師研修制度は 4 年間の大学教育終了後に 4 年間の医学部卒前教育があり, さらに $3 \sim 7$ 年の卒後 研修を受け，国家試験に合格すると医師の資格を取得 します。その後専門医を目指す医師は専門医教育研修 プログラムを受け，専門医試験に臨みます．専門医の 研修施設は ACGME (Accreditation Council for Graduate Medical Education，卒後医学教育機構）が認定業 務を行っており，指定された研修施設で必要とされる 症例数を一定の期間に経験すると受験資格を取得でき ます (図).その後筆記および口頭試験に合格すると 専門医になることができます.

現在米国には 90 万人の医師がいますが，このうち ABMSにより1つ以上の専門医資格を取得した医師は 約 85\%となっています. 現在 ABMS が認定している領 域は 24 領域であり, その内訳はアレルギー・免疫学,

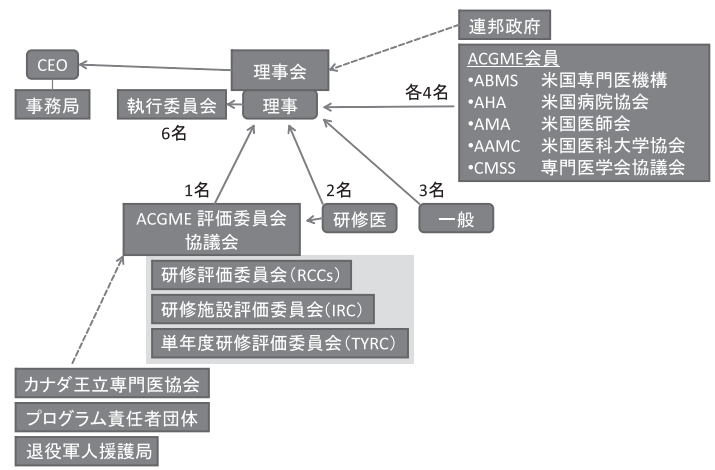

図 卒後臨床研修認定協議会

Accreditation Council for Graduate Medical Education (ACGME)

麻酔科学, 消化器外科学, 皮膚科学, 救急医学, 家庭 医学, 内科学, 遺伝学, 神経外科学, 核医学, 産婦人 科学, 眼科学, 整形外科学, 耳鼻科学, 病理学, 小児 科学, 物療医学・リハビリテーション (以下, リハ) 医 学, 形成外科学, 予防医学, 精神神経医学, 放射線医 学, 外科学, 胸部外科学, 泌尿器医学となっています. この 24 領域のそれぞれに複数の subspecialty があり, 全部で 110 の subspecialty で構成されています (表).

ABMSを構成する組織はACCME（Accreditation Council for Continuing Medical Education, 医学教育 維持機構), 前述の ACGME, AHA（American Hospital Association, 米国病院機構), AMA (American Medical Association, 米国医師会), AAMC (Association of American Medical Colleges, 米国医系大学機構), CMSS (Council of Medical Specialty Society, 医学専門性機関), ECFMG (Educational Commission for Foreign Medical Graduates, 外国人医学卒後教育機構), FSMB (Federation of State Medical Boards of the United States, 米国連邦医学機関), NBME (National Board of Medical Examiners, 医学国家試験機構) となっており, 専門医 制度のあり方，質の維持に関しても検討されています. 現在の専門医取得医師数は 752,000 人, subspecialty 
表 ABMS が認定している 24 領域とその subspecialty

\begin{tabular}{|c|c|c|}
\hline Board & General Certificate (s) & Subspecialty Certificate \\
\hline Allergy \& Immunology & Allergy \& Immunology & \\
\hline Anethesiology & Anethesiology & $\begin{array}{l}\text { Critical care medicine } \\
\text { Hospice \& Palliative medicine } \\
\text { Pain medicine }\end{array}$ \\
\hline Colon \& Rectal Surgery & Colon \& Rectal Surgery & \\
\hline Dermatology & Dermatology & $\begin{array}{l}\text { Clinical \& Laboratory dermatological immunology } \\
\text { Dermatopathology } \\
\text { Pediatric dermatology }\end{array}$ \\
\hline Emergency medicine & Emergency medicine & $\begin{array}{l}\text { Hospice \& Palliative medicine } \\
\text { Medical toxicology } \\
\text { Pediatric emergency medicine } \\
\text { Sports medicne } \\
\text { Undersea \& Hyperbaric medicine }\end{array}$ \\
\hline Family medicne & Family medicne & $\begin{array}{l}\text { Adolescent medicine } \\
\text { Geriatric medicne } \\
\text { Hospice \& Palliative medicne } \\
\text { Sleep medicne } \\
\text { Sports medicine }\end{array}$ \\
\hline Internal medicne & Internal medicne & $\begin{array}{l}\text { Adolescent medicne } \\
\text { Advanced heart failure \& Transplant cardiology } \\
\text { Cardiovascular disease } \\
\text { Clinical cardiac electrophysiolosy } \\
\text { Critical care medicine } \\
\text { Endocrinoogy, Diabetes \& Metabolism } \\
\text { Gastroenterology } \\
\text { Geriatric medicine } \\
\text { Hematology } \\
\text { Hospice \& Palliative medicine } \\
\text { Infectious disease } \\
\text { Interventional cardiology } \\
\text { Medical oncology } \\
\text { Nephrology } \\
\text { Pulmonary disease } \\
\text { Rheumatology } \\
\text { Sleep medicine } \\
\text { Sports medicine } \\
\text { Transplant hepatology }\end{array}$ \\
\hline Medical genetics & $\begin{array}{l}\text { Clinical biochemical genetics } \\
\text { Clinical cytogenetics } \\
\text { Clinical genetics (MD) } \\
\text { Clinical molecular genetics }\end{array}$ & $\begin{array}{l}\text { Medical biochemical genetics } \\
\text { Molecular genetic pathology }\end{array}$ \\
\hline Nuclear medicine & Nuclear medicine & \\
\hline Neurological surgery & Neurological surgery & \\
\hline Obstetrics \& Gynecology & Obstetrics \& Gynecology & $\begin{array}{l}\text { Critical care medicine } \\
\text { Gynecologic oncology } \\
\text { Hospice \& Palliative medicine } \\
\text { Maternal \& Fetal medicine } \\
\text { Reproductive } \\
\text { Endocrinology/Infertility }\end{array}$ \\
\hline
\end{tabular}




\begin{tabular}{|c|c|c|}
\hline Orthopaedic surgery & Orthopaedic surgery & $\begin{array}{l}\text { Orthopaedic sports medicine } \\
\text { Surgery of the hand }\end{array}$ \\
\hline Otolaryngology & Otolaryngology & $\begin{array}{l}\text { Neurology } \\
\text { Pediatric otolaryngology } \\
\text { Plastic surgery within the head \& neck } \\
\text { Sleep medicine }\end{array}$ \\
\hline Pathology & $\begin{array}{l}\text { Anatomic pathology \& Clinical pathology } \\
\text { Pathology - anatomic } \\
\text { Pathology - Clinical }\end{array}$ & $\begin{array}{l}\text { Blood banking/Transfusion medicne } \\
\text { Cytopathology } \\
\text { Dermatopathology } \\
\text { Pathology - Chemical } \\
\text { Pathology - Forensic } \\
\text { Pathology - Hematologic } \\
\text { Pathology - Medical microbiology } \\
\text { Pathology - Molecular genetics } \\
\text { Pathology - Pediatric } \\
\text { Neuropathology }\end{array}$ \\
\hline Pediatrics & Pediatrics & $\begin{array}{l}\text { Adolescent medicine } \\
\text { Child abuse pediatrics } \\
\text { Developmental - Behavioral pediatrics } \\
\text { Hospice \& Palliative medicine } \\
\text { Medical toxicology } \\
\text { Neonatal - Perinatal medicine } \\
\text { Neurodevelopmental disabilities } \\
\text { Pediatric cardiology } \\
\text { Pediatric critical care medicine } \\
\text { Pediatric emergency medicine } \\
\text { Pediatric endocrinology } \\
\text { Pediatric gastroenterology } \\
\text { Pediatric hematology - oncology } \\
\text { Pediatric infectious diseases } \\
\text { Pediatric nephrology } \\
\text { Pediatric pulmonology } \\
\text { Pediatric rheumatology } \\
\text { Pediatric transplant hepatology } \\
\text { Sleep medicine } \\
\text { Sports medicine }\end{array}$ \\
\hline Physical medicine \& Rehabilitation & Physical medicine \& Rehabilitation & $\begin{array}{l}\text { Hospice \& Palliative medicine } \\
\text { Neuromuscular medicine } \\
\text { Pain medicine } \\
\text { Pediatric rehebilitation medicine } \\
\text { Spinal cord injury medicine } \\
\text { Sports medicine }\end{array}$ \\
\hline Plastic surgery & Plastic surgery & $\begin{array}{l}\text { Plastic surgery within the head \& neck } \\
\text { Surgery of the hand }\end{array}$ \\
\hline Preventive medicine & $\begin{array}{l}\text { Aerospace medicine } \\
\text { Occupational medicine } \\
\text { Public health \& General preventive } \\
\text { medicine }\end{array}$ & $\begin{array}{l}\text { Medical toxicology } \\
\text { Undersea \& Hyperbaric medicine }\end{array}$ \\
\hline Psychiatry \& Neurology & $\begin{array}{l}\text { Psychiatry } \\
\text { Neurology } \\
\text { Neurology with special qualification } \\
\text { in child neurology }\end{array}$ & $\begin{array}{l}\text { Addiction psychiatry } \\
\text { Child \& Adolescent psychiatry } \\
\text { Forensic psychiatry } \\
\text { Geriatric psychiatry } \\
\text { Hospice \& Palliative medicine } \\
\text { Neurodevelomental disabilities } \\
\text { Neuromuscular medicine }\end{array}$ \\
\hline
\end{tabular}




\begin{tabular}{|c|c|c|}
\hline & & $\begin{array}{l}\text { Pain medicine } \\
\text { Psychosomatic medicine } \\
\text { Sleep medicine } \\
\text { Vascular neurology }\end{array}$ \\
\hline Radiology & $\begin{array}{l}\text { Diagnostic radiology } \\
\text { Radiation oncology } \\
\text { Radiologic physics }\end{array}$ & $\begin{array}{l}\text { Hospice \& Palliative medicine } \\
\text { Neuroradiology } \\
\text { Nuclear radiology } \\
\text { Pediatric radiology } \\
\text { Vascular \& Interventional radiology }\end{array}$ \\
\hline Surgery & $\begin{array}{l}\text { Surgery } \\
\text { Vascular surgery }\end{array}$ & $\begin{array}{l}\text { Hospice \& Palliative medicine } \\
\text { Pediatric surgery } \\
\text { Surgery of the hand } \\
\text { Surgical critical care }\end{array}$ \\
\hline Thoracic surgery & Thoracic surgery & Congenital cardiac surgery \\
\hline Urology & Urology & Pediatric urology \\
\hline
\end{tabular}

取得者数は 179,000 人です.

ABMS では 1917 年に眼科学の専門医制度から始ま り，1991年に遺伝学で 24 領域目が認定されています. さらに 1960 年台に家庭医学と内科学から資格更新制 度が始まり，現在はすべての領域で資格更新が必要と なっています，資格更新にはそれぞれの臨床医学に現 役として従事する必要があり，再資格試験に合格する ことにより継続できるシステムとなっています.

\section{講演 II}

\section{海外の専門医制度についてードイツ連邦共和国一}

堀映

福祉村病院長寿医学研究所所長

ドイツの医師免許，学位を持ち，ハノーバー医科大 学病理学・法医学センター神経病理学研究所で教授を 務められ，専門医試験の試験官として活動されておら れた堀映先生からドイツの専門医制度に関する講演が ありました。

ドイツの医学部には入学試験がなく，1年間 2 学期 制であり，12 学期計 6 年間で卒業となります。就学 中に 2 回, 卒業前に 1 回の計 3 回の国家試験があり, こ れに合格すると医師の資格を取得できます。卒後教育 に関しては医師会がすべてを統括しており，指定研修 施設で指導者の下に専門教育を受けることになります.

医師会は原則として州ごとに存在し，医師全員が加 入する義務を持ち，医師に関する法的拘束力を持つ団 体として位置付けられています。したがってすべての 領域の専門医の試験, 認可についても医師会が権限を
持っています.

専門医を目指す医師は医師会から認可された施設 で，医師会から認可された指導医の下で研修を行いま す. 受験資格取得にあたっては，一定の症例数，定め られた検査法，治療法の経験が必要となり，それぞれ 指導医から証明書を受ける必要があります。試験はほ とんどが口頭試問により行われ，試験長は医師会役員 で，医師会が各専門分野に応じて $2 \sim 3$ 名を試験官に 指定して試験を実施します。

専門医の領域は臨床科として麻酔科, 労働医学, 眼 科, 外科, 産婦人科, 耳鼻咽喉科, 皮膚 - 性病科, 内 科，小児・青少年医学科，小巟・青少年精神医学，口 腔顎顔面外科, 脳神経外科, 神経学, 核医学, 病理 学, 物療およびリハ医学, 精神医学, 身体精神医学, 放射線医学, 放射線療法, 輸液医学, 泌尿器科学など があり, さらに基礎医学的な専門医領域として，解剖 学, 生化学, 人類遺伝学, 衛生・環境医学, 薬理学, 法 医学などが含まれます。また領域により subspecialty が設定されており，例えば外科では総合外科，血管外 科, 小览外科, 整形外科 - 外傷外科, 形成外科 - 美容 外科など, 内科では一般医 (家庭医), 胃腸科, リウ マチ科，内分泌・糖尿病科などとなっています。

特徴的なのは専門医資格があくまで臨床能力の証明 であるため，アカデミックな経歴とは無関係で，論文 や学位などの実績は全く必要がないことです。また 「一般医」という領域は開業医を目指す医師のための 専門医で，この場合専門医指導資格を持つ開業医の下 で研修を受けることができます。 